University of Nebraska - Lincoln

DigitalCommons@University of Nebraska - Lincoln

Agronomy \& Horticulture -- Faculty Publications

Agronomy and Horticulture Department

1984

\title{
Identification of Chromosomes with Secondary Constrictions in Melilotus Species
}

\author{
S. E. Schlarbaum \\ Kansas State University \\ L. B. Johnson \\ United States Department of Agriculture \\ Herman J. Gorz \\ United States Department of Agriculture \\ Francis A. Haskins \\ University of Nebraska-Lincoln, fhaskins@neb.rr.com
}

Follow this and additional works at: https://digitalcommons.unl.edu/agronomyfacpub

Part of the Plant Sciences Commons

Schlarbaum, S. E.; Johnson, L. B.; Gorz, Herman J.; and Haskins, Francis A., "Identification of Chromosomes with Secondary Constrictions in Melilotus Species" (1984). Agronomy \& Horticulture -Faculty Publications. 307.

https://digitalcommons.unl.edu/agronomyfacpub/307

This Article is brought to you for free and open access by the Agronomy and Horticulture Department at DigitalCommons@University of Nebraska - Lincoln. It has been accepted for inclusion in Agronomy \& Horticulture -Faculty Publications by an authorized administrator of DigitalCommons@University of Nebraska - Lincoln. 


\title{
Identification of chromosomes with secondary constrictions in Melilotus species
}

\section{S. E. Schlarbaum \\ L. B. Johnson \\ H. J. Gorz}

F. A. Haskins
The authors are, respectively, former postdoctoral research associate, and professor, Department of Plant Pathology, Throckmorton Hall, Kansas State University, Manhattan, KS 66506; supervisory research geneticist, USDA-ARS, and George Holmes Professor of Agronomy, Department of Agronomy, University of Nebraska, Lincoln, NE 68583. Dr. Schlarbaum's present address: Department of Forestry, Wildlife and Fisheries, University of Tennessee, Knoxville, TN 37901. Research supported by National Science Foundation grant PCM 8022556. Contribution no. 82-575-J, Department of Plant Pathology, Kansas State University, Agricultural Experiment Station, Manhattan, Kansas 66506. Research was done in cooperation with the Nebraska Agricultural Experiment Station and the U.S. Department of Agriculture, Agricultural Research Service. Please address reprint requests to Dr. S. E. Schlarbaum.

(C 1984, American Genetic Association.

\begin{abstract}
Secondary constrictions were determined in one chromosome pair in the complements of $M$. infesta, $M$. macrocarpa, $M$. italica (subgenus Micromelilotus), and $M$. alba and $M$. officinalis (subgenus Melilotus). The karyotypes of $M$. infesta and $M$. macrocarpa were found to be similar. Chromosomes of $M$. italica were larger than the chromosomes of the other four Melilotus species. The chromosome size in M. italica suggests the presence of large chromosomes in an ancestral or pro-Melilotus prototype. The chromosomes with satellites of $M$. infesta and $M$. macrocarpa appear to differ in morphology from the satellite chromosomes of $M$. alba and $M$. officinalis by a paracentric inversion. The morphology of the satellite chromosomes in $M$. italica is thought to represent a more primitive type than in the other Melilotus species studied.
\end{abstract}

The SWEetclover Genus, Melilotus Adans., contains forage and nitrogen fixing species of agricultural importance. Taxonomically, Melilotus is divided into two subgenera ${ }^{10},(E u)$ Melilotus Schulz and Micromelilotus Schulz. Isely ${ }^{4}$ considers the subgenus Melilotus to consist of nine biennial species, including the commercially important M. alba Desr. and M. officinalis (L.) Lam., while the subgenus Micromelilotus contains 11 annual species, few of which have economic value as crops ${ }^{14}$. Other taxonomists, most notably Suvorov ${ }^{16}$, consider the genus to contain a greater number of species.

The chromosome number of many Melilotus species, $2 n=2 x=16$, was determined early in this century ${ }^{2,11}$. Karyotype analyses of all Melilotus species, with the exception of the dubious $M$. bicolor Boiss \& Bal., were reported by Kita ${ }^{5,6}$. Chromosomes with satellites were found in all species except $M$. infesta Guss., M. macrocarpa Goss. et Dur., and $M$. italica (L.) Lam., which belong to $M i$ cromelilotus. Secondary constrictions could not be defined in the chromosomes of these three species.

The present study was undertaken to delineate the occurrence and positions of secondary constrictions in the chromosome complements of $M$. infesta, $M$. macrocarpa, and $M$. italica. Additionally, a comparison was made between the satellite chromosomes of these species and the satellite chromosomes of $M$. alba and M. officinalis for evidence of karyotypic evolution.

\section{Materials and Methods}

Seed of each species was obtained from the collection of Melilotus germplasm that is kept in cold storage at the University of Nebraska. M. infesta (Bdn. 61-98) and M. macrocarpa (Bdn. 61-97) were from seed of Algerian accessions. Seed of $M$. italica (Bdn. 523) came from a collection made in Portugal. Seed of commercially available cultivars of $M$. alba (Evergreen-Lot 14C) and $M$. officinalis (Yukon-F.C. 40594) were used in the study.

Actively growing root tips from onemonth-old seedlings grown in clay pots were utilized. The root tips were placed in ice water for 24 hours (for a detailed description, see Singh and Tsuchiya ${ }^{12}$ ) and then fixed in a 3:1 mixture of ethanol:propionic acid in which a small amount of ferric chloride had been dissolved as a mordant. After 3-4 days in a fixative, the root tips were hydrolyzed in $1 \mathrm{~N} \mathrm{HCl}$ at $60^{\circ} \mathrm{C}$ for 6 minutes and stained in acetocarmine for at least 3 days. After sufficient staining, the meristematic tissue was squashed 
in 45 percent acetic acid. Dividing cells in the meristematic region were isolated and analyzed.

For the Micromelilotus species, the karyological interpretations were made on the chromosome complement of a representative cell from each species in which the chromosomes were well spread and the secondary constrictions were obvious. From these cells, karyotypes were constructed by arranging the chromosomes in pairs considering the total length, centromere position, and gross morphology. The chromosome pairs were generally arranged in gradation from the longest to the shortest pair of the complement. Satellite chromosome morphology in $M$. alba and $M$. officinalis cells was studied in a number of preparations.

\section{Results}

The chromosome number of $2 n=2 x=16$, as previously reported ${ }^{2,5,11}$, was confirmed in all species. Numerous cells were observed (ca. 20 ) in each species in which chromosome morphology was able to be characterized. Secondary constrictions in one chromosome pair were found to exist in $M$. infesta, $M$. macrocarpa, and $M$. italica (Figures 1, 2, 3, and $4 A-C$ ). The existence of satellite chromosomes in $M$. alba ${ }^{3}$ and $M$. officinalis ${ }^{1}$ also was reaffirmed (Figure $4 D$ and $E$ ).

The chromosome complement of $M$. infesta is shown in Figure $1 A$. A secondary constriction was found in the largest chromosome pair near the centromere in the short arm (Figures $1 B$ and $4 A$ ). At somatic prophase, this chromosome pair appeared to be heterochromatic in contrast to the majority of other chromosomes that appeared to stain normally (Figure $5)$. The karyotype shows the presence of many nonmetacentric chromosomes (Figure $1 B$ ).

Figure $2 A$ shows the somatic chromosomes of $M$. macrocarpa. The chromosomes with satellites in this species were the largest chromosomes in the complement (Figure $2 B$ ) and appear to be heterochromatic, as in $M$. infesta. In general, the karyotype of $M$. macrocarpa closely resembles the $M$. infesta karyotype. However, the short arm bearing the satellite body in M. macrocarpa was shorter, relatively, than the corresponding short arm in $M$. infesta (Figure $4 A$ and $B$ ). The chromosomes of $M$. macrocarpa, excluding the satellite chromosome pair, did not stain as deeply as chromosomes of the other species.

Overall, the chromosomes of $M$. italica were the largest of the species studied (Figure $3 A$ ). The satellite bodies in this species were the same or of greater length than the long arms of the satellite chromosomes (Figures $3 B$ and $4 C$ ). The larger chromosomes in the kar-

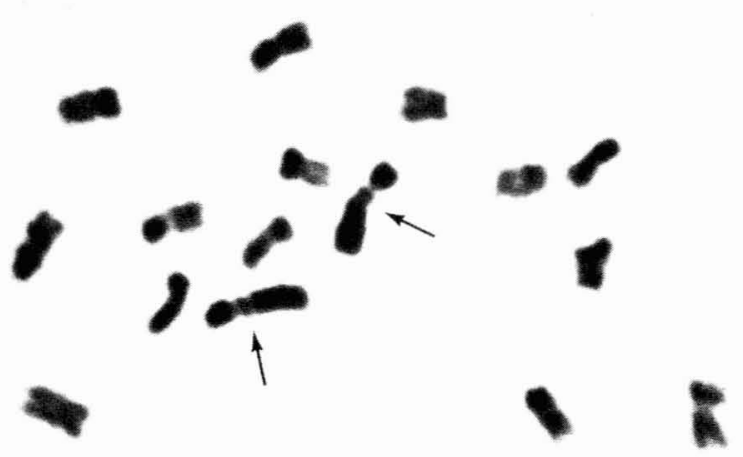

A

$5 \mu \mathbf{m}$

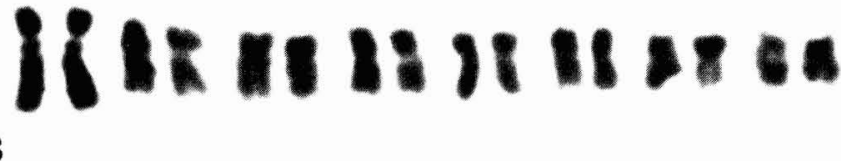

FIGURE $1 A$ shows somatic chromosomes of Melilotus infesta, $2 n=2 x=16$; arrows indicate satellite chromosomes. $B$ - karyotype of $M$. infesta; chromosomes cut from $A$. yotype were metacentric while the smaller chromosomes tended to have nonmedian centromeres (Figure $3 B$ ). The chromosomes of $M$. italica stained very deeply, suggesting a heterochromatic nature.

The satellite chromosomes of $M$. alba and $M$. officinalis are different in morphology from the preceding species (Figure $4 A-E$ ).
Both species have small satellite bodit tached to the short arms (Figure $4 D$ E).

\section{Discussion}

Comparisons of the karyotypes of $h$ festa, M. macrocarpa, and $M$. italic served in the present study with thos:

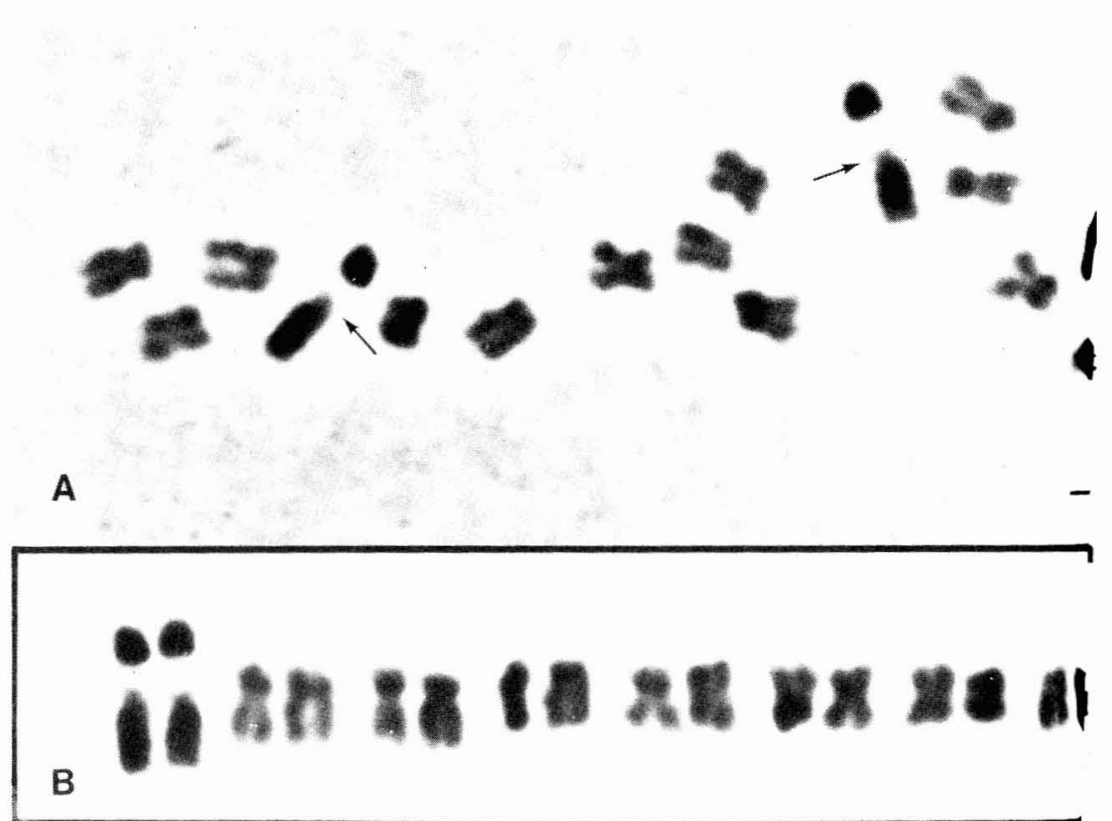

FIGURE $2 A$ shows somatic chromosomes of Melilotus macrocarpa, $2 n=2 x=16$; arrow satellite chromosomes. $B$-karyotype of $M$. macrocarpa; chromosomes cut from $A$. 


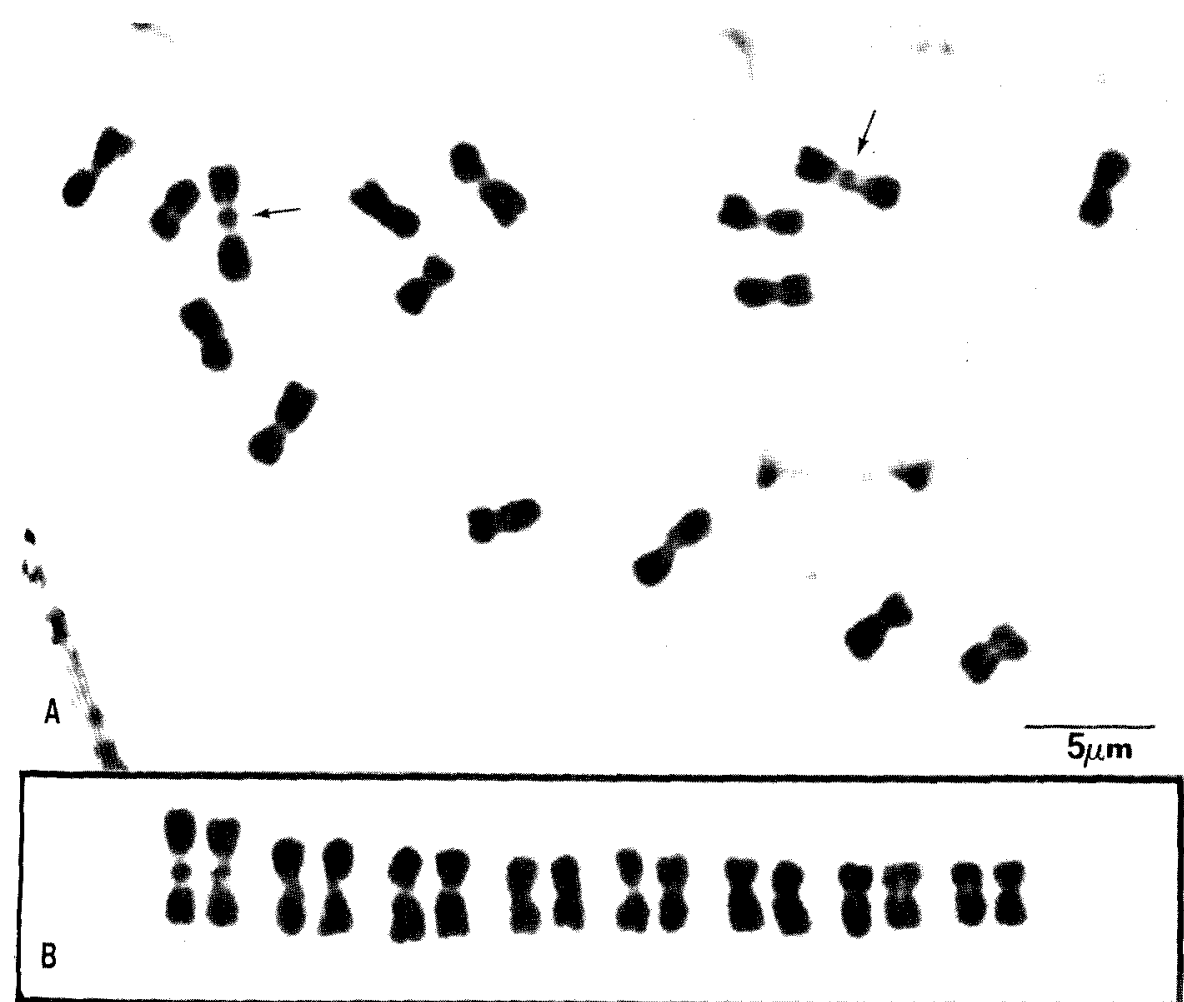

, FIGURE $3 A$ shows somatic chromosomes of Melilotus italica, $2 n=2 x=16$; arrows indicate satellite thromosomes. $B$ - karyotype of $M$. italica; chromosomes cut from $A$.

sented by $\mathrm{Kita}^{6}$ show a general agreement with the exception of the satellite chromosomes. In each species, it appears that Kita misidentified the secondary constriction as the nimary constriction. The small size of the short arm of the satellite chromosomes in $M$. infesta and $M$. macrocarpa causes a close proximity between the primary and secondary constrictions making distinction very difficult (Figure $4 A$ and $B$ ). Also, excessive chromosome contraction and deep staining often obscured the primary constriction in many cells. In the case of $M$. italica, overstaining of the presumably heterochromatic satellite chromosomes probably confounded Kita's obserrations.

The chromosomes of $M$. macrocarpa are similar to those of $M$. infesta, yet appear substantially larger. This is in contrast with the results of Kita ${ }^{5,6}$ who observed no significant difference in chromosome size between the two species. Comparison of the chromosomes of $M$. infesta and $M$. macrocarpa by chromosome index (short arm/long arm ratio) and relative length, following the methodology of Tjio and Hagberg ${ }^{17}$, reveals no critical dfference between the karyotypes. The size differential found in the present study is probably due to differences in chromosome intraction between the two cells shown of each species and to artifacts normally encountered with the squash technique for slide preparations.

The differences in size between chromosomes of $M$. italica and those of other Melilotus species have been reported previously ${ }^{1,5}$ In many plant species, it has been observed that the evolution of karyotypes proceeds from large chromosomes in primitive species to smaller chromosomes in specialized species ${ }^{15}$. Chromosome studies in two leguminous genera, Trifolium ${ }^{9}$ and Medicago (Schlarbaum, unpub.), indicate karyotypic evolution has occurred in this manner. This suggests that the chromosome size of $M$. italica may be indicative of the chromosome size in an ancestral Melilotus or pro-Melilotus species. This hypothesis is supported by the morphological observations of Suvorov ${ }^{16}$, who considered $M$. italica to characterize the features of an ancestral Melilotus type, although he recognized that paleobotanic information was lacking for the genus. There is some doubt that the present karyotype of $M$. italica should be considered as a basikaryotype ${ }^{13}$ for a Melilotus prototype, as it is semi-asymmetrical, indicating an advanced evolutionary state 7,15 . The functional basis of the large size and heterochromatic nature of the $M$. italica chromosomes is not known.

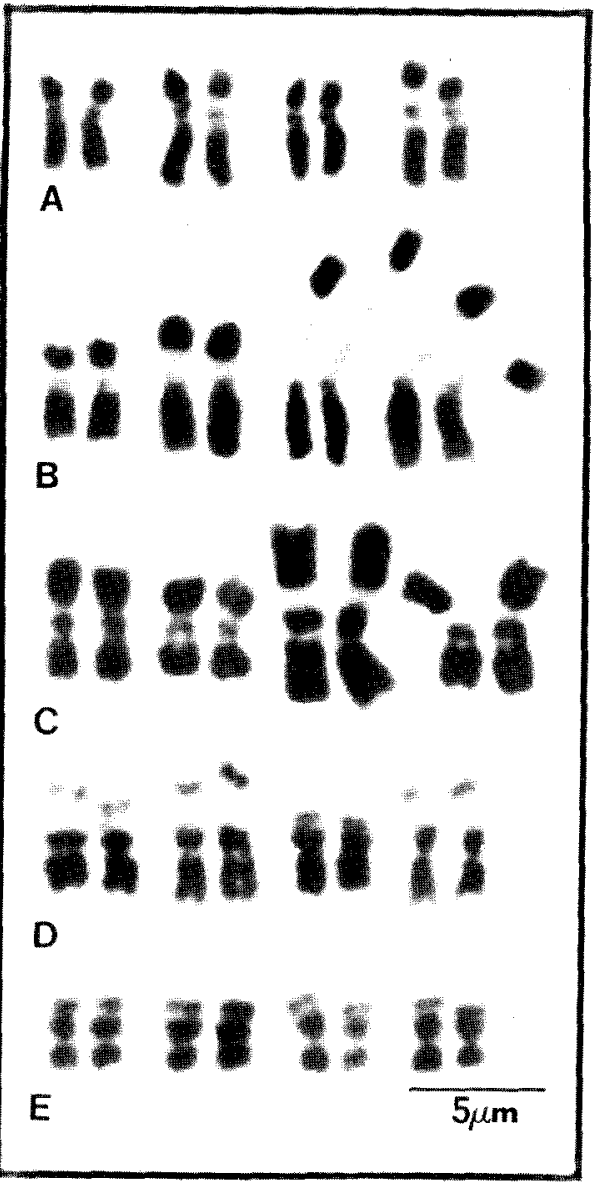

FIGURE \& Satellite chromosomes of Melilotus species isolated from different somatic cells. $A-M$ infesta: $B-M$. macrocarpa; $C-M$. italica; $D-M$. alba; $E-M$. officinalis.

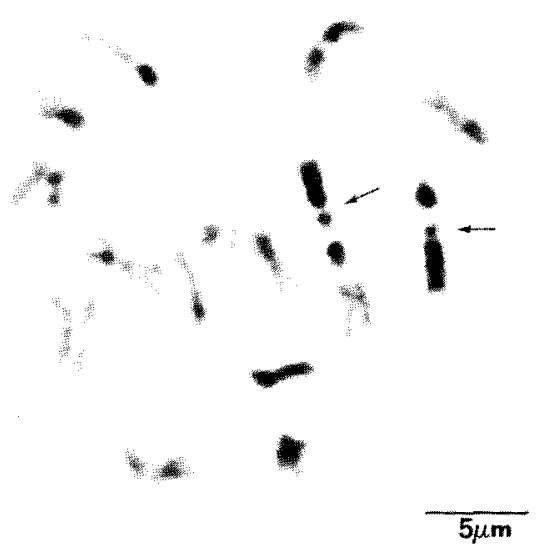

FIGURE 5 Chromosomes of Melilotus infesta at somatic prophase; arrows indicate heterochromatic satellite chromosomes.

The satellite chromosomes of the species studied can be grouped into three types: type I-satellite large, short arm large as in $M$. italica (Figure 4C); type II-satellite large, 
short arm small as in $M$. infesta and $M$. macrocarpa (Figure $4 A$ and $B$ ), and type IIIsatellite small, short arm large as in $M$. alba and $M$. officinalis (Figure $4 D$ and $E$ ). The differences between types II and III could result from a paracentric inversion with breakage sites in the short arm and satellite body. The satellite chromosome morphology of type I possibly represents a more primitive state than satellite chromosomes of types II and III.

After observing alteration of the nucleolus organizer chromosome system due to irradiation in Trillium kamtschaticum Pall., Matsuura ${ }^{8}$ proposed that one method of satellite chromosome origin was a paracentric inversion of a terminally located nucleolus organizer region (NOR) to an intercalary position. If the origin of satellite chromosomes in Melilotus proceeded according to this hypothesis, the morphology of the satellite chromosomes in $M$. italica (type I) appears similar to what would be expected from a paracentric inversion in a chromosome with a terminal NOR present in a primitive Melilotus karyotype.

\section{References}

1. Clarke, A. E. The number and morphology of chromosomes in the genus Melilotus. Univ. Calif. Publ. Bot. 17:435-444. 1934.

2. Darlington, C. D. and A. P. Wylie. Chromosome Atlas of Flowering Plants. George Allen and Unwin, London. 1955.

3. FRYER, J. R. Cytological studies in Medicago, Melilotus and Trigonella. Can. J. Res. 3:3-50. 1930.

4. ISELY, D. Keys to sweet clovers (Melilotus). Iowa Acad. Sci. 61:119-131. 1954.

5. KiTA, F. Studies on the genus Melilotus (sweetclover) with special reference to interrelationships among species from a cytological point of view. J. Fac. Agri. Hokkaido Univ. 54:25-122. 1965.

6. Studies on morphology of the somatic chromosomes of the genus Melilotus (sweetclover). Jpn. J. Bot. 19:149-174. 1966.

7. LeVITSKY, G. A. The karyotype in systematics. Bull. App. Bot. Genet. Plant Breed. 27:220-240. 1931.
8. Matsuura, H. Chromosome studies on Trill kamtschaticum Pall. XVI. Alterations of nucleolus-chromosome system due to irradia Cytologia 12:271-288. 1942.

9. PRitchard, J. A. Number and morpholog chromosomes in African species in the genus folium L. Aust. J. Agric. Res. 13:1023-1029. 1

10. Schulz, O. E. Monographie der Gattung $M$ lotus. Bot. Jahrb. 29:660-735. 1901.

11. SENN, H. A. Chromosome number relations in the Leguminosae. Bibliog. Genetica 12:1751938.

12. Singh, R. J. and T. TsuchiYA. An impre Giemsa $\mathrm{N}$-banding technique for the identifice of barley chromosomes. J. Hered. 73:227-229. 1

13. Sinoto, Y. and D. SATO. Basikaryotype an analysis. Cytologia 10:529-538. 1940.

14. SMITH, W. K. and H. J. GorZ. Sweetclover provement. Adv. Agron. 17:164-231. 1965.

15. Stebirins, G. L. Chromosomal Evolutior Higher Plants. Addison-Wesley, Reading, MA.

16. Suvorov, V. V. Sweetclover-Melilotus (To. Adans. Em. In Flora of Cultivated Plants o U.S.S.R. E. N. Sinskaya, Ed. 13:426Translation from Russian as OTS 60-51198. Dept. Commerce, Washington, D.C. 1950

17. TJIO, J. H. and A. HAGBerg. Cytological st on some x-ray mutants of barley. An. Estaci Au'a Dei 2:149-167. 1951. 